\title{
HUBUNGAN ANTARA CORPORATE GOVERNANCE DAN VARIABEL PENGURANG MASALAH AGENSI
}

\author{
Zaenal Arifin \\ Fakultas Ekonomi Universitas Islam Indonesia
}

\begin{abstract}
The main objective of this research is to investigate whether there are a significant relationship between corporate governance and agency-problem-reducing variables. The corporate governance is concern on all stakeholders' interest while the agency variables are concern on one of the most important stakeholders' that is the stockholders-interest. Theoretically, there should be a significant relationship between the corporate governance and the agency-problem-reducing variables. Using 52 Indonesian listed companies in 2001 that had been investigated by Indonesian Institute for Corporate Governance (IICG) for the companies' practice of corporate governance and presented on SWA Magazine, this research found that no relationship between the corporate governance and the agency-problem-reducing variables. There are some possible explanations for this finding. First, reducing agency problems does not perceived (by investor) affecting the companies' practice of corporate governance. Second, the bonding mechanisms to reduce the free cash flows by increasing the dividend payment or increasing the debt and monitoring by the independent board of directors are not an effective mechanism to reduce agency problems. So these mechanisms do not correlate to the companies' practice of corporate governance. Third, the score of corporate governance released by IICG are not valid. Further investigations are needed to find the true explanation.
\end{abstract}

Key words: Corporate Governance, Masalah Agensi

\section{LATAR BELAKANG MASALAH}

Adalah suatu fenomena yang banyak ditemui ketika perusahaan bertambah besar maka pemilik perusahaan tidak mampu lagi mendanai operasi dan perkembangan perusahaan sehingga pemilik memutuskan mengambil dana dari luar seperti dari perbankan atau pasar modal. Dana yang berasal dari perbankan jumlahnya relatif kecil dan biaya modalnya pada umumnya relatif mahal sedangkan dana dari pasar modal jumlahnya relatif besar dan biaya modalnya relatif kecil. Oleh karena itu maka banyak perusahaan besar memutuskan untuk go public dengan menjual saham ke pasar modal.

Menjual saham ke pasar modal berarti menjual sebagian kepemilikan kepada orang lain. Dengan demikian pemilik lama harus mau berbagi kekuasaan dengan pemilik (pemegang saham) baru. Namun pemilik lama pada umumnya tidak mau begitu saja melepas kontrolnya atas perusahaan. Kontrol tersebut akan tetap pada pemilik lama (meskipun kepemilikan sudah dibagi-bagi) asal pemilik lama masih memiliki saham mayoritas. Fenomena inilah yang banyak terjadi di Indonesia.

Adanya kepemilikan mayoritas akan memunculkan kemungkinan konflik kepentingan antara pemegang saham mayoritas dan pemegang 
saham minoritas. Konflik ini dapat dilihat dalam kerangka masalah agensi. Sebagai prinsipal dalam hal ini adalah pemegang saham minoritas dan pemegang saham mayoritas yang ikut mengelola perusahaan bertindak sebagai agen. Permasalahan agensi di Indonesia seperti dikemukakan di atas memang agak berbeda dengan permasalahan agensi di Amerika Serikat dimana konflik kepentingan terjadi antara pemegang saham secara umum, yang memiliki porsi kepemilikan relatif kecil, dengan manajer yang juga memiliki kepemilikan relatif kecil. Meskipun konfliknya agak berbeda namun teori agensi yang dikembangkan di Amerika Serikat, yang merupakan upaya mencari mekanisme untuk meminimalkan konflik agensi, dalam batas tertentu juga dapat diadopsi di Indonesia.

Artikel pertama yang menganalisis masalah agensi di perusahaan sekaligus mengusulkan mekanisme untuk mengatasinya adalah yang ditulis oleh Jensen dan Meckling (1976). Mereka mengatakan bahwa masalah agensi dapat dikurangi dengan memberikan insentif- seperti bonus dan stock option, melakukan monitoring- seperti adanya board of directors, dan melakukan pengekangan diri (bonding)- seperti meningkatkan jumlah dividen dan meningkatkan jumlah hutang. Mereka juga menawarkan mekanisme untuk meningkatkan kepemilikan manajer agar masalah agensi dapat diminimalisir. Jensen (1986) menawarkan mekanisme pengurangan free cash flows agar dana yang dapat disalahgunakan manajer dapat dibatasi sehingga masalah agensi juga menjadi kecil. Pengurangan free cash flows (potensial) ini dapat dilakukan dengan cara meningkatkan distribusi kas kepada pemegang saham baik lewat dividen maupun pembelian kembali saham dan dengan cara meningkatkan jumlah hutang.

Berkaitan dengan efektifitas pengawasan dewan komisaris, ada kecenderungan bahwa pengawasannya kurang efektif seperti ditemukan oleh Mace (1986). Namun jika dalam dewan komisaris ada dewan komisaris independen, menurut temuan Weisbach (1988) pengawasannya menjadi efektif. Mekanisme yang juga terbukti efektif adalah mekanisme pasar corporate control seperti ditemukan oleh Morck, Shleifer, dan Vishny (1989), adanya pemegang saham besar seperti dikemukakan Shleifer dan Vishny (1986) dan Mc Connell dan Servaes (1990), kepemilikan yang terkonsentrasi seperti dikemukakan oleh Shleifer dan Vishny (1997).

Mekanisme pengurang masalah agensi yang diuraikan di atas memang untuk mengurangi masalah agensi di Amerika Serikat sehingga perlu dipilah mekanisme apa yang secara teoritis logis dapat juga dipakai di Indonesia. Pemberian insentif, pengawasan oleh dewan komisaris independen, melakukan bonding untuk mengurangi free cash flows adalah beberapa mekanisme yang masih dapat diterapkan di Indonesia. Peningkatan kepemilikan manajer nampaknya tidak efektif karena kepemilikan manajer sudah cukup tinggi, demikian pula mekanisme kepemilikan besar dan atau 
terkonsentrasi karena pada saat ini kepemilikannya sudah terkonsentrasi. Mekanisme yang diperkirakan juga tidak efektif adalah penggunaan pasar corporate control karena pasar corporate control di Indonesia belum berjalan efektif.

Meskipun bukan merupakan satu-satunya permasalahan dalam membentuk good corporate governance namun penanganan masalah agensi merupakan suatu faktor yang sangat penting untuk mewujudkan good corporate governance terutama pada perusahaan yang sudah go public. Sementara saat ini corporate governance merupakan permasalahan yang sangat disorot oleh investor di pasar modal. Hasil survei yang dilakukan oleh tim McKinsey, Coombes dan Watson (2000), memperlihatkan bahwa investor bersedia memberi premium kepada perusahaan yang bagus corporate governance-nya. Besar premium untuk negara-negara Asia yang disurvey adalah antara $20-27 \%$, dan Indonesia adalah yang tertinggi premiumnya yaitu $27 \%$.

Walaupun merupakan sesuatu yang penting, masih banyak perusahaan yang kurang peduli terhadap corporate governance. Di saat yang sama orang luar (outsider) akan mengalami banyak kendala untuk mengetahui dengan persis baik buruknya corporate governance perusahaan dan hal ini diperburuk dengan keengganan beberapa perusahaan untuk dinilai corporate governance-nya. Kesulitan ini terlihat dari pengalaman majalah Swa (dimuat di edisi 20 September - 3 Oktober 2001) ketika mengadakan penilaian terhadap corporate governance perusahaan go public. Ternyata masih banyak perusahaan yang enggan memberikan respon atas pertanyaan-pertanyaan yang diajukan tim peneliti Swa sehingga perusahaan tersebut sulit untuk dinilai corporate governance-nya. Keengganan ini membuat keakuratan penilaian corporate governance oleh majalah Swa menjadi dipertanyakan.

Jika masalah agensi merupakan faktor penting dalam corporate governance dan di sisi yang lain orang luar mengalami kendala dalam menilai corporate governance maka menjadi kajian yang menarik jika kita berusaha mengkaitkan antara hasil penilaian corporate governance oleh lembaga-lembaga tertentu dengan variabel agensi yang sudah diteorisasikan dan diuji secara empiris keandalannya. Mengetahui keterkaitan antara nilai corporate governance yang dipublikasikan oleh majalah Swa dengan kebijakan dividen, kebijakan hutang, porsi kepemilikan orang dalam, dan ada tidaknya komisaris independen, misalnya, akan memberi gambaran tentang validitas penilaian corporate governance oleh lembaga tersebut. Penelitian ini akan melakukan analisis tentang kaitan antara nilai corporate governance oleh lembaga tertentu (seperti majalah Swa dan lembaga lain jika ditemukan) dengan variabel-variabel agensi. 


\section{KAJIAN LITERATUR DAN HIPOTESIS}

\section{Corporate Governance dan Masalah Agensi}

Kaen (2003) mendefinisikan corporate governance sebagai sesuatu tentang siapa yang mengontrol perusahaan dan mengapa dia mengontrol. Sementara itu Forum for Corporate Governance in Indonesia (FCGI) mendefinisikannya sebagai seperangkat aturan yang menetapkan hubungan antara pemegang saham, pengurus, pihak kreditur, pemerintah, karyawan, serta para pemegang kepentingan intern dan ekstern lainnya sehubungan dengan hak-hak dan kewajiban mereka. Secara singkat FCGI mendefinisikan corporate governance sebagai sistem yang mengarahkan dan mengendalikan perusahaan.

Menilik definisi corporate governance di atas nampak bahwa salah satu unsur penting dalam corporate governance adalah adanya hubungan agensi. Hubungan agensi hanya membatasi pada hubungan antara penyandang dana perusahaan (pemegang saham dan kreditor) dengan manajemen sedangkan corporate governance melihat dalam cakupan yang lebih luas dengan melibatkan semua pemegang kepentingan (stakeholders) perusahaan dalam rangka mengendalikan perusahaan. Pentingnya hubungan agensi sebagai salah satu unsur corporate governance nampak pada, misalnya, prinsip-prinsip internasional mengenai corporate governence yang dicatat oleh FCGI seperti dikutip berikut ini.

Prinsip-prinsip corporate governance mencakup (1) adanya hakhak pemegang saham yang harus diberi informasi yang benar dan tepat waktu, ikut berperan serta dalam pengambilan keputusan mengenai perubahan-perubahan yang mendasar, dan turut memperoleh bagian keuntungan, (2) adanya perlakuan sama terhadap para pemegang saham terutama kepada pemegang saham minoritas dan asing, dengan keterbukaan (transparency) informasi penting, melarang pembagian untuk pihak sendiri, dan melarang perdagangan saham oleh orang dalam (insider trading), (3) diakuinya peran pemegang saham, bersama pemegang kepentingan yang lain, dalam menciptakan kekayaan, lapangan kerja, dan perusahaan yang sehat, (4) adanya pengungkapan (disclosure) yang akurat dan tepat pada waktunya serta transparansi atas hal penting bagi kinerja perusahaan, kepemilikan, serta pemegang kepentingan, dan (5) adanya tanggungjawab pengurus dalam manajemen, pengawasan manajemen serta pertanggungjawaban kepada perusahaan dan para pemegang saham. Membaca prinsip-prinsip tersebut nampak bahwa pemegang saham merupakan pihak yang paling mendapatkan perhatian dalam corporate governance. Berdasarkan uraian di atas penulis mengajukan hipotesis mayor: Ada hubungan yang signifikan antara nilai corporate governance dan variabel pengurang masalah agensi. Hipotesis mayor ini akan dirinci dalam hipotesis-hipotesis minor yang nantinya akan diuji. 


\section{Mekanisme Untuk Mengurangi Masalah Agensi (Variabel Agensi)}

Jensen dan Meckling (1976) mengidentifikasi ada dua cara untuk mengurangi kesempatan manajer melakukan tindakan yang merugikan investor, yaitu (1) investor luar melakukan pengawasan (monitoring) dan (2) manajer sendiri melakukan pembatasan atas tindakan-tindakannya (bonding). Pada satu sisi, kedua kegiatan tersebut akan mengurangi kesempatan penyimpangan oleh manajer sehingga nilai perusahaan akan meningkat sedangkan pada sisi yang lain keduanya akan memunculkan biaya sehingga akan mengurangi nilai perusahaan. Jensen dan Meckling (1976) menyatakan bahwa calon investor akan mengantisipasi adanya kedua biaya tersebut ditambah dengan kerugian yang masih muncul meskipun sudah ada monitoring dan bonding, yang disebut residual loss. Antisipasi atas ketiga biaya yang didefinisikan sebagai biaya agensi (agency cost) ini nampak pada harga saham yang terdiskon saat perusahaan menjual sahamnya.

\section{Mekanisme monitoring}

Ada beberapa mekanisme untuk mengurangi biaya agensi. Berikut adalah mekanisme-mekanisme kontrol yang dapat dipakai untuk mengurangi masalah agensi.

\section{- Pembentukan Dewan Komisaris}

Pembentukan dewan komisaris adalah salah satu mekanisme yang banyak dipakai untuk memonitor manajer. Namun demikian penelitian Mace (1986) menemukan bahwa pengawasan dewan komisaris terhadap manajemen pada umumnya tidak efektif. Ini terjadi karena proses pemilihan dewan komisaris yang kurang demokratis dimana kandidat dewan komisaris sering dipilih oleh manajemen sehingga setelah terpilih tidak berani memberi kritik terhadap manajemen. Namun jika dewan didominasi oleh anggota dari luar (independent board of director) maka monitoring dewan komisaris terhadap manajer menjadi efektif seperti ditemukan oleh Weisbach (1988). Efektifitas monitoring oleh dewan komisaris ini juga ditemukan oleh Morck, Shleifer, dan Vishny (1989). Perusahaan go public di Indonesia pada saat ini sebagain sudah memiliki dewan komisaris independen namun sebagian yang lain belum. Melihat temuan Weisbach dan Morck et al maka penulis mengajukan hipotesis:

H1 : Ada hubungan antara terdapat atau tidaknya dewan komisaris independen nilai corporate governance

- Pasar Corporate Control

Mekanisme yang lebih efektif dibandingkan dengan pembentukan dewan komisaris adalah melalui pasar corporate control, yaitu takeover 
(pengambilalihan). Manne (1965) menyatakan bahwa adanya pasar untuk corporate control dimana perusahaan yang menurun nilainya akibat adanya masalah agensi akan diambil alih oleh perusahaan lain, merupakan mekanisme yang lebih bagus sehingga masalah agensi dapat dikurangi.

Secara empiris banyak yang mendukung efektifitas pasar corporate control ini dalam mengurangi masalah agensi. Jensen dan Ruback (1983) misalnya menemukan bahwa nilai gabungan antara perusahaan yang mengakuisisi dan yang diakuisisi meningkat setelah adanya akusisi. Disamping itu Palepu (1985) menemukan bahwa perusahaan yang diakuisisi pada umumnya memang perusahaan yang buruk kinerjanya. Easterbrook dan Fischel (1991) juga menyatakan bahwa takeover merupakan mekanisme corporate governance yang penting di Amerika Serikat dimana tanpa adanya mekanisme ini maka kebebasan manajer (managerial discretion) akan sangat sulit dikontrol secara efektif.

Keefektifan mekanisme pasar corporate control masih mengundang beberapa pertanyaan. Pertama, biaya takeover relatif mahal sehingga hanya perusahaan yang sudah benar-benar tidak terkelola dengan baik yang layak untuk diambilalih. Tingginya biaya takeover ini menurut Grossman dan Hart (1980) karena si pengambilalih tidak sekedar hanya membayar atas kondisi perusahaan pada saat ini namun juga membayar kenaikan laba yang akan diperoleh ketika pengambilalihan tersebut nantinya sukses. Hal ini sesuai dengan Morck, Shleifer, dan Vishny (1989) yang menemukan bahwa takeover merupakan cara efektif untuk mengontrol manajemen namun biayanya mahal. Kedua, akusisi sebenarnya justru meningkatkan biaya agensi jika perusahaan yang mengambil alih membayar terlalu tinggi. Seperti yang dikemukakan oleh Morck, Shleifer, dan Vishny (1990), dalam banyak kasus, munculnya takeover justru merupakan bukti adanya masalah agensi pada perusahaan yang melakukan takeover karena manajernya ingin meningkatkan ukuran perusahaan sehingga kekuasaan mereka juga meningkat. Jensen (1993) juga mencatat bahwa hanya sedikit dari aktivitas akuisisi di Amerika Serikat pada tahun 80-an yang memang merupakan upaya untuk mendisplinkan manajer. Ketiga, pengambilalihan membutuhkan adanya pasar modal yang likuid yang memungkinkan pengakuisisi memperoleh dana banyak dalam waktu singkat. Maka kemudian muncullah junk bond yang digunakan untuk membiayai akuisisi. Banyak perusahaan yang bangkrut akibat pendanaan dengan junk bond tersebut dan hal inilah yang menjadi salah satu sebab mengapa gelombang aktivitas akuisisi di Amerika Serikat berhenti. 
Penelitian ini tidak menganalisis mekanisme pasar corporate control karena mekanisme ini tidak dipakai di Indonesia.

- Pemegang Saham Besar

Mekanisme yang juga banyak dipakai untuk mengawasi manajemen adalah melalui pemegang saham besar (large outside shareholder) yang biasanya merupakan lembaga keuangan seperti investment banking, perusahaan asuransi, perusahaan dana pensiun, perusahaan reksa dana, dan bank. Model pengurangan masalah agensi yang dibuat Jensen dan Meckling (1976) mengasumsikan bahwa pemegang saham terdiri dari investor-investor kecil. Oleh karena itu biaya monitoring terhadap manajemen pada investorinvestor tersebut akan sangat besar sehingga mereka cenderung tidak melakukan monitoring.

Shleifer dan Vishny (1986) membuat model dengan memasukkan adanya pemegang saham besar. Dari model tersebut ditemukan bahwa pemegang saham besar layak melakukan pengawasan yang lebih teliti, yang tentu saja terkait dengan bertambah besarnya dana pengawasan yang disediakan, karena manfaat yang akan mereka peroleh juga besar. Penelitian Mc Connell dan Servaes (1990) menguatkan pendapat tersebut dengan ditemukannya hubungan positif signifikan antara Tobin's q dengan kepemilikan institusional.

Di Amerika Serikat, kepemilikan dalam jumlah besar terutama yang mencapai mayoritas (di atas 50\%) sangat jarang ditemui. Meskipun demikian kepemilikan saham di Amerika pada saat ini tidak sepenuhnya menyebar. Shliefer dan Vishny (1986), misalnya menemukan bahwa banyak keluarga atau investor kaya yang memiliki porsi saham yang cukup signifikan dan bahkan Holderness dan Sheehan (1988) menemukan ratusan perusahaan publik di Amerika Serikat yang salah satu investornya menguasai lebih dari 50\% saham. Temuan-temuan ini merupakan bukti bahwa pemeang saham besar memang dapat digunakan untuk mengontrol manajer agar masalah agensi menjadi minimal.

Di luar Amerika Serikat (dan Inggris), kepemilikan saham dalam jumlah besar merupakan hal biasa. Jerman, bank-bank besar banyak yang mengontrol hak suara di perusahaan-perusahaan melalui proxy voting arrangements. Di samping itu Gordon dan Smith juga memperkirakan sekitar $80 \%$ perusahaan besar di Jerman memiliki pemegang saham non bank yang menguasai lebih dari $25 \%$ porsi kepemilikan. Pada perusahaan yang relatif kecil, keluarga yang biasanya menjadi pemilik mayoritas dengan mekanisme piramid. Dengan mekanisme piramid maka pemegang saham pengendali akhir (ultimate shareholder) dapat mengontrol banyak perusahaan dengan 
modal yang minimal. Di Jepang kepemilikan bank yang tinggi di perusahaan juga ditemukan meskipun tidak setinggi kepemilikan bank di Jerman. Di Perancis kepemilikan dalam jumlah besar yang umum terjadi (OECD (1995)) dan di negara-negara yang lain peruahaanperuahaan pada umumnya ada pemilik utamanya baik berbentuk mayoritas atau tidak mayoritas. Pemilik utama tersebut pada beberapa negara Asia dan Amerika Latin adalah pendiri perusahaan atau anak cucunya.

Konsisten dengan temuan Mc Connell dan Servaes (1990) bahwa adanya pemegang saham besar akan meningkatkan kinerja perusahaan di Amerika Serikat, Gorton dan Schmid (1996) menemukan bahwa kepemilikan besar oleh bank maupun non bank di Jerman juga meningkatkan kinerja perusahaan. Sementara itu Kaplan dan Minton (1994) menemukan bahwa di Jepang, perusahaan yang ada pemegang saham yang besarnya memiliki kecenderungan yang lebih besar untuk mengganti manajer ketika kinerja perusahaan memburuk. Temuan-temuan ini membuktikan bahwa pemegang saham besar memang efektif sebagai mekanisme untuk mengurangi masalah agensi.

Pemegang saham besar memang efektif mengurangi masalah agensi namun mekanisme ini juga menimbulkan biaya. Biaya yang jelas muncul adalah karena pemegang saham besar terbatas kesempatannya untuk melakukan diversifikasi sehingga dia menanggung risiko yang lebih besar. Namun, jika melihat banyaknya perusahaan di dunia ini yang dimiliki oleh pemegang saham besar, keterbatasan melakukan diversifikasi nampaknya tidak menjadi penghalang yang berarti untuk memiliki saham perusahaan dalam jumlah besar. Permasalahan yang lebih menonjol justru terletak pada adanya kekuasaan pemegang saham besar yang cukup berpengaruh sehingga sangat mungkin digunakan untuk memutuskan sesuatu yang menguntungkan kepentingan pribadinya dan kepentingan tersebut bertentangan dengan kepentingan investor atau stakeholders yang lain. Karena memiliki kontrol yang kuat, pemegang saham besar mungkin saja membuat keputusan untuk membagikan dividen hanya pada dirinya sendiri dan pemegang saham minoritas yang lain tidak mendapat dividen tersebut.

Bukti pemanfaatan hak kontrol pemegang saham besar dapat dilihat dari adanya premium yang besar pada harga saham yang dibeli dalam jumlah besar dibandingkan dengan harga saham ketika dibeli dalam jumlah kecil. Zingales (1994) misalnya menemukan adanya premium yang cukup signifikan pada penjualan saham dalam jumlah besar di Itali. Sementara itu Barclay dan Holderness (1992) tidak 
menemukan premium yang signifikan di Amerika Serikat. Temuan ini mungkin dapat ditafsirkan bahwa kemungkinan pemegang saham besar melakukan tindakan yang merugikan pemegang saham minoritas adalah lebih besar di Itali dibandingkan dengan kemungkinan dilakukannya oleh pemegang saham besar di Amerika Serikat.

Bukti kemungkinan adanya tindakan yang merugikan pemegang saham minoritas juga dapat dilihat dari studi tentang struktur kepemilikan. Morck, Shleifer, dan Vishny (1998) misalnya menemukan bahwa ketika kepemilikan seseorang masih di bawah $10 \%$, maka kenaikan kepemilikan akan meningkatkan laba perusahaan namun setelah kepemilikannya di atas 10\% maka meningkatnya kepemilikan justru akan menurunkan laba perusahaan. Temuan ini dapat ditafsirkan bahwa ketika kepemilikan seorang pemegang saham masih kecil maka peningkatan kepemilikan tersebut akan mengurangi masalah agensi karena hak kontrol dapat dilakukan dengan efisien. Namun ketika kepemilikan seseorang sudah cukup untuk melakukan kontrol dengan efisien dan kepemilikan tersebut ditambah maka dia akan memiliki kemampuan kontrol yang berlebihan. Kemampuan kontrol yang berlebihan ini akan memunculkan masalah agensi baru yaitu berupa peluang untuk mengambil tindakan yang menguntungkan diri sendiri dan merugikan investor yang lain.

Kondisi kepemilikian perusahaan go public di Indonesia menunjukkan bahwa ada kelompok tertentu yang memiliki kepemilikan cukup besar, yang biasanya adalah orang dalam perusahaan (manajer), sehingga akan memunculkan konflik kepentingan dengan pemegang saham minoritas. Oleh karena itu hipotesis yang diajukan adalah:

H2 : Ada hubungan negatif antara nilai corporate governance dengan Kepemilikan saham besar.

- Kepemilikan Terkonsentrasi

Mekanisme pengurangan biaya agensi yang agak mirip dengan mekanisme pemegang saham besar adalah mekanisme lewat kepemilikan yang lebih terkonsentrasi. Kepemilikan dikatakan lebih terkonsentrasi jika untuk mencapai kontrol dominasi atau mayoritas dibutuhkan penggabungan lebih sedikit investor. Shleifer dan Vishny (1997) mengemukakan bahwa jika kontrol dapat dipegang oleh semakin sedikit investor maka akan semakin mudah kontrol tersebut dijalankan. Dibandingkan dengan mekanisme pemegang saham besar, kepemilikan terkonsentrasi memiliki kekuatan kontrol yang lebih rendah karena mereka tetap harus melakukan koordinasi untuk menjalankan hak kontrolnya. Namun pada sisi yang lain mekanisme kepemilikan terkonsentrasi juga memiliki kemungkinan yang lebih kecil un- 
tuk munculnya peluang bagi kelompok investor yang terkonsentrasi untuk mengambil tindakan yang merugikan investor yang lain. Karena kepemilikan perusahaan di Indonesia cenderung ada pemegang saham besarnya maka variabel kepemilikan terkonsentrasi tidak dianalisis

- Pasar Manajer

Fama (1980) menyatakan bahwa masalah agensi akan sangat berkurang dengan sendirinya karena manajer akan dicatat kinerjanya oleh pasar manajer baik yang ada dalam perusahaan sendiri maupun yang berasal dari luar perusahaan. Lapisan manajer atas akan digantikan oleh manajer lapisan di bawahnya jika kinerjanya kurang memuaskan. Persaingan di pasar manajer ini akan memaksa manajer bertindak sebaik mungkin untuk kemajuan perusahaan. Namun mekanisme pasar manajer ini tidak dapat sepenuhnya berjalan karena pasar manajer bukan merupakan pasar yang sempurna. Kelangkaan tenaga manajer dan sikap perlawanan dari pihak manajer agar posisinya tidak diganti adalah faktor-faktor yang menghambat diterapkannya mekanisme pasar manajer untuk kepentingan pengurangan masalah agensi. Makanisme ini juga menurut hemat penulis tidak berjalan di Indonesia sehingga tidak dianalisis.

\section{Mekanisme kontrol dengan peningkatan kepemilikan manajer}

Teori struktur kepemilikan Jensen dan Meckling (1976) mengisyaratkan bahwa ada hubungan positif antara kepemilikan manajer $(\alpha)$ dengan nilai perusahaan. Namun, uji empiris yang dilakukan oleh Demsetz dan Lehn (1985) tidak menemukan adanya hubungan positif antara struktur kepemilikan dan nilai perusahaan yang diproxy dengan laba akuntansi. Penyebabnya kemungkinan besar adalah karena pola hubungan antara kepemilikan manajer dan nilai perusahaan tidak merupakan hubungan linear sederhana.

Stulz (1988) mengembangkan teori struktur kepemilikan dan mendapatkan bahwa hubungan antara kepemilikan manajer dan nilai perusahaan adalah non-monotonic. Pada tingkat $\alpha$ yang rendah, nilai perusahaan akan meningkat dengan meningkatnya $\alpha$ karena pada saat itu insentif manajer untuk bertindak 'konsumtif' menurun. Pada level $\alpha$ yang tinggi, nilai perusahaan justru menurun ketika $\alpha$ meningkat karena adanya pengaruh management entrenchment, yaitu suatu posisi kepemilikan dimana manajer dapat dengan bebas memaksimumkan utilitasnya tanpa takut adanya hostile takeover, perlawanan dari dewan komisaris, maupun proxy fight oleh investor besar.

Teori struktur kepemilikan dari Stulz (1988) ini didukung oleh beberapa penelitian empiris. Morck, Shleifer, dan Vishny (1988) menemukan 
bahwa Tobin's $q$ pada awalnya meningkat dengan meningkatnya $\alpha$, namun kemudian menurun ketika ada penambahan $\alpha$ lagi setelah $\alpha$ mencapai tingkat 5\%. Tingkat titik balik $\alpha$ dapat berbeda dengan berbedanya karakteristik sampel terbukti McConnell dan Servaes (1990) menemukan bahwa Tobin's q tetap meningkat sampai dengan level $\alpha$ antara $40-50 \%$.

Mekanisme ini sudah dapat ditampung dalam hipotesis ketiga sehingga tidak perlu diajukan hipotesis baru.

\section{Mekanisme kontrol dengan bonding}

Jensen (1986) melihat masalah keagenan dari sudut ketersediaan uang yang dapat digunakan manajer untuk kegiatan 'konsumtif'. Dana tersebut adalah free cash flows yaitu kelebihan dana yang ada di perusahaan setelah semua proyek investasi yang menghasilkan net present value positif dilaksanakan. Jika biaya agensi ingin dikurangi maka free cash flows harus dikurangi terlebih dahulu. Dengan kata lain manajer harus menunjukkan kepada pemegang saham bahwa dia telah melakukan upaya menahan diri (bonding) untuk tidak menciptakan peluang melakukan penyimpanganpenyimpangan dengan cara memperkecil dana yang dapat disimpangkan, yaitu free cash flows.

\section{- Bonding Dengan Meningkatkan Hutang}

Cara bonding yang disarankan oleh Jensen (1986) adalah dengan meningkatkan jumlah hutang. Semakin besar hutang maka semakin banyak dana kas yang harus dikeluarkan oleh perusahaan untuk membayar bunga dan angsuran dengan demikian akan mengurangi jumlah dana kas yang disimpan perusahaan. Jensen dan Meckling (1976) juga menyarankan memakai peningkatan hutang untuk mengurangi biaya agensi meskipun dengan alasan yang berbeda, yaitu supaya outside equity tidak bertambah sehingga konflik antara investor luar dan manajemen tidak meningkat.

Uji empiris bonding dengan menaikkan hutang sebenarnya mengacu pada hasil penelitian empiris tentang struktur modal. Beberapa penelitian seperti dirangkum oleh Harris dan Raviv (1991) menunjukkan bahwa ada hubungan yang positif antara jumlah hutang dengan nilai perusahaan. Dalam konteks teori agensi, hasil korelasi positif antara jumlah hutang dan nilai perusahaan diinterpretasikan sebagai adanya pengurangan masalah agensi ketika hutang perusahaan meningkat. Mekanisme ini dapat digunakan di Indonesia sehingga penulis mengajukan hipotesis:

H3 : Ada hubungan positif antara nilai corporate governance dan porsi hutang perusahaan. 
- Bonding Dengan Meningkatkan Dividen

Disamping meningkatkan hutang, free cash flow juga dapat dikurangi dengan meningkatkan dividen tunai. Semakin besar dividen yang ditetapkan oleh perusahaan maka perusahaan harus mengeluarkan dana kas yang semakin besar sehingga yang tersisa di perusahaan menjadi kecil. Dengan alasan yang berbeda, Rozeff (1982) juga menyarankan peningkatan dividen untuk mengurangi biaya agensi karena meningkatnya dividen akan meningkatkan kemungkinan perusahaan mengambil dana dari luar (bukan dari dana internal) sehingga perusahaan semakin sering dimonitor oleh investor baru. Makanisme ini juga dapat dijalankan di Indonesia sehingga penulis mengajukan hipotesis:

H4 : Ada hubungan posistif antara nilai corporate governance dan dividend payout ratio.

\section{METODE PENELITIAN}

Sampel penelitian ini adalah perusahaan-perusahaan yang dinilai indeks corporate governance-nya oleh majalah SWA dan IICG pada tahun 2001 yaitu sebanyak 52 perusahaan.

Data yang diperlukan dalam penelitian ini adalah data sekundar. Skor corporate governance dimuat di majalah Swa edisi 20 September - 3 Oktober 2001 sedangkan data tentang ada tidaknya komisaris independen, ada tidaknya kepemilikan saham besar, rasio hutang, dan dividend payout ratio diperoleh dari Indonesian Capital Market Directory.

Uji terhadap empat hipotesis minor dilakukan dengan melihat signifikan tidaknya koefisien korelasi antara skor corporate governance dengan masing-masing variabel agensi yaitu adanya komisaris independen, adanya kepemilikan saham besar, bonding dengan hutang, dan bonding dengan dividen. Analisis dua variabel ini agak sulit ditingkatkan menjadi uji pengaruh karena secara teoritis variabel agensi merupakan bagian dari variabel corporate governance dan bukan faktor yang mempengaruhi corporate governance. Karena alasan inilah maka dalam penelitian ini, variabel agensi dan corporate governance hanya diuji korelasinya.

\section{HASIL PENELITIAN}

\section{Statistik Diskriptif}

Penelitian ini memiliki lima variabel penelitian yaitu Skor Corporate Governance (CORGOV), Dewan Komisaris Independen (DKI), Kepemilikan Saham Besar (KSB), Debt Ratio (DR), dan Dividend Payout Ratio. Variabel KSB terdiri dari dua variabel yaitu kepemilikan saham besar dengan ke- 
tentuan di atas 50\% (KSB1) dan dengan batasan 30\% (KBS2). Gambaran umum dari variabel penelitian nampak dalam Tabel 1 di bawah ini.

Tabel 1: Statistik Diskriptif Variabel Penelitian

\begin{tabular}{|l|c|c|c|c|c|c|}
\hline & CORGOV & DKI & KSB1 & KSB2 & DR & DPR \\
\hline Mean & 43.55038 & 0.288462 & 0.615385 & 0.826923 & 0.623913 & 0.118181 \\
\hline Median & 39.53500 & 0.000000 & 1.000000 & 1.000000 & 0.615000 & 0.000000 \\
\hline Maximum & 78.94000 & 1.000000 & 1.000000 & 1.000000 & 1.510000 & 0.645800 \\
\hline Minimum & 10.00000 & 0.000000 & 0.000000 & 0.000000 & 0.100000 & 0.000000 \\
\hline Std. Dev. & 19.88038 & 0.457467 & 0.491251 & 0.382005 & 0.303121 & 0.177012 \\
\hline Observations & 52 & 52 & 52 & 52 & 46 & 52 \\
\hline
\end{tabular}

Dari Tabel 1 di atas nampak bahwa rata-rata skor corporate governance adalah 43,55. Angka ini di bawah cut-off yang digunakan oleh IICG/SWA yaitu 45,00, yang secara tersirat dari pengelompokan dua tabel yang termuat dalam majalah SWA. Dari tabel juga diketahui bahwa hanya $28,85 \%$ perusahaan yang memiliki dewan komisaris independen. Jumlah perusahaan yang memiliki seorang pemilik mayoritas berjumlah $61,54 \%$ dan yang memiliki seorang pemilik yang dominan sebanyak $82,69 \%$. Sementara itu rata-rata debt ratio perusahaan adalah $62,39 \%$ dengan standar deviasi $30,3 \%$ dan rata-rata dividend payout rationya adalah $11,82 \%$ dengan standar deviasi $17,7 \%$. Data debt ratio hanya 46 perusahaan karena ada 6 sampel perusahaan perbankan sehingga tidak tepat dihitung debt ratio-nya.

\section{Hasil Uji Hipotesis}

Hasil uji hipotesis yang menyatakan bahwa ada hubungan antara nilai corporate governance dan variabel-variabel agensi ternyata tidak terbukti. Tabel 2 di bawah ini memperlihatkan koefisien korelasi antara nilai corporate governance dan variabel agensi berserta tingkat signifikansinya.

Tabel 2: Hasil Uji Koralasi antara Nilai Corporate Governance dan Variabel Agensi

\begin{tabular}{|c|c|c|c|c|c|c|}
\hline & & DKI & KSB1 & KSB2 & DR & DPR \\
\hline CORGOV & Pearson Correlation & .017 & .146 & .086 & -.172 & .097 \\
\hline & Sig. (2-tailed) & .906 & .303 & .547 & .253 & .493 \\
\hline & $\mathbf{N}$ & 52 & 52 & 52 & 46 & 52 \\
\hline
\end{tabular}

Hipotesis pertama yang menyatakan bahwa perusahaan yang memiliki dewan komisaris independen memiliki nilai corporate governance yang lebih tinggi tidak terbukti secara statistik empiris karena hubungan antara variabel dewan komisaris independen dan nilai corporate governance hanya 0.017 , suatu nilai korelasi yang sangat rendah. 
Hipotesis kedua yang menyatakan bahwa ada hubungan negatif antara nilai corporate governance dengan kepemilikan saham besar juga tidak terbukti secara statistik empiris. Hasil empiris justru menunjukkan arah koefisien yang berbeda dengan arah koefisien yang dihipotesiskan. Variabel kepemilikan besar dalam penelitian ini menggunakan dua ukuran yaitu kepemilikan mayoritas (porsi kepemilikan di atas 50 persen) dan kepemilikan dominan (porsi kepemilikan 30 persen ke atas). Kedua ukuran kepemilikan tersebut memberikan hasil yang tidak berbeda.

Hipotesis ketiga menyatakan bahwa ada hubungan positif antara nilai corporate governance dan porsi hutang perusahaan. Hipotesis ini tidak terbukti secara empiris dan arah koefisien korelasi yang ditemukan berbeda dengan arah koefisien korelasi yang dihipotesiskan. Hipotesis keempat menyatakan bahwa hubungan positif antara nilai corporate governance dan dividend payout ratio. Hipotesis ini juga ternyata tidak terbukti secara empiris. Koefisien korelasi keduanya hanya 0,097.

Tidak terbuktinya empat hipotesis yang diajukan dalam penelitian ini dapat dijelaskan kedalam beberapa kemungkinan. Kemungkinan pertama adalah memang tidak ada hubungan antara nilai corporate governance dengan variabel agensi pada perusahaan yang terdaftar di pasar modal Indonesia. Perusahaan yang berupaya mengurangi masalah agensi tidak dipersepsi telah melakukan good corporate governance. Ini mungkin terjadi karena fokus masalah agensi hanya pada kepentingan investor sedangkan corporate governance menampung kepentingan seluruh stakeholder perusahaan.

Kemungkinan kedua, variabel agensi yang diuji dalam penelitian ini bukan merupakan variabel agensi yang efektif untuk menurunkan masalah agensi di Indonesia. Komisaris independen, large shareholder, bonding dengan meningkat hutang, dan bonding dengan meningkatkan dividen memang efektif untuk mengurangi masalah agensi di Amerika Serikat dimana konflik agensi terjadi antara manajer dan pemegang saham. Di Indonesia konflik agensi terjadi antara pemegang saham mayoritas/dominan dengan pemegangs saham minoritas. Bisa jadi perbedaan tipe masalah agensi ini dan juga faktor-faktor lain baik faktor ekonomi maupun nonekonomi menjadi sebab tidak efektifnya keempat mekanisme pengurangan masalah agensi. Jika keempat mekanisme di atas tidak efektif untuk mengurangi masalah agensi maka bisa jadi akan ada hubungan yang signifikan antara nilai corporate governance dengan variabel agensi jika mekanisme pengurang masalah agensinya efektif.

Kemungkinan ketiga, nilai corporate governance yang dipublikasikan oleh majalah SWA, yang dijadikan sebagai rujukan penerapan corporate governance dalam penelitian ini, tidak akurat. Ketidakakuratan ini dapat muncul karena ada beberapa perusahaan di Bursa Efek Jakarta 
yang cenderung tertutup dalam memberikan informasi tentang pelaksanaan corporate governance di perusahaannya. Jika nilai corporate governance lebih akurat dan persisten dalam beberapa tahun ada kemungkinan akan ditemukan adanya hubungan yang signifikan antara nilai corporate governance dan variabel agensi.

Dari tiga kemungkinan penjelasan di atas, mana yang paling tinggi probabilitas kebenarannya? Jawaban sahih atas pertanyaan ini memerlukan penelitian lebih lanjut namun nampaknya agak sulit untuk memilih penjelasan pertama (bahwa memang tidak ada hubungan antara baik buruknya pelaksanaan corporate governance dengan variabel agensi) sebagai penjelasan yang paling benar. Penjelasan kedua dan ketiga menurut hemat penulis lebih masuk akal dijadikan sebagai penjelasan yang benar.

KESIMPULAN

Penelitian ini mengajukan pertanyaan apakah ada hubungan antara nilai corporate governance dan variabel agensi. Nilai corporate governance diambil dari publikasi majalah SWA tentang nilai (skor) corporate governance 52 perusahaan di Bursa Efek Jakarta. Variabel agensi yang dipakai dalam penelitian ini adalah mekanisme pengurang masalah agensi berupa empat variabel yaitu dewan komisaris independen, kepemilikan besar, bonding dengan meningkatkan hutang, dan bonding dengan meningkatkan dividen. Hasil uji empiris menunjukkan bahwa tidak terdapat hubungan yang signifikan antara nilai corporate governance dan keempat variabel agensi.

Tidak signifikannya hubungan antara nilai corporate governance dan variabel agensi ini mungkin disebabkan oleh tidak efektifnya keempat variabel agensi dalam mengurangi masalah agensi pada perusahaan di Indonesia atau mungkin disebabkan oleh tidak akuratnya skor corporate governance atau memang tidak ada hubungan antara nilai corporate governance dengan variabel agensi. Menurut hemat penulis, kemungkinan yang terakhir ini probabilitas kebenarannya sangat kecil.

Penelitian berikutnya mungkin dapat menelusur lebih lanjut tentang efektifitas variabel agensi yang digunakan dalam penelitian ini dalam mengurangi masalah agensi untuk mengetahui apakah penjelasan kedua benar atau tidak. Penelitian berikutnya juga dapat menguji validitas dari skor corporate governance dengan membandingkannya dengan nilai corporate governance yang diterbitkan oleh lembaga yang sama pada tahuntahun berikutnya atau yang diterbitkan oleh lembaga lain (peluang untuk melakukan hal ini agak sulit karena keterbatasan jumlah lembaga penerbit skor corporate governance dan sedikitnya perusahaan yang mau dinilai corporate governance-nya). Penelitian ini nantinya dapat untuk menguatkan atau membantah penjelasan penulis yang kedua. 


\section{DAFTAR PUSTAKA}

Coombes, Paul dan Mark Watson (2000), Three Surveys on Corporate Governance, The McKinsey Quarterly, No. 4, 2000

Easterbrook, F. H. dan D. R. Fischel, (1983), Voting in Corporate Law, Journal of Law and Economics, 26, pp 395-427

Fama, E. H., (1980), Agency Problem and the Theory of the Firm, Journal of Political Economy, Vol. 88

Forum for Corporate Governance in Indonesia (FCGI), Corporate Governance Tata Kelola Perusahaan, http://www.fcgi.or.id

Grossman, S. J, dan O. D. Hart (1980), Takeover bids, the Free-Rider Problem, nad the Thoery of the Corporation, Bell Journal of Economics, 11, pp. 42-64

Harris, Milton dan A. Raviv (1991), The Theory of Capital Structure, the Journal of Finance, Vol XLVI, No. 1, pp 297 - 355

Holderness, C G dan D P Sheehan, (1991), Monitoring the Owner: the Case of Turner Broadcasting, Journal of Fianacial Economics, 30, pp. 325-346

Jensen, C. Michael, (1986), Agency Costs of Free Cash Flow, Corporate Finance, and Takeovers, American Economic Review, Vol. 76, No.2, May

(1990), The Modern Industrial Revolution, Exit, and the Failure of Internal Control Systems, Journal of Finance, 48, pp. 831-880

Jensen, C M dan W. H. Meckling (1976), Theory of the Firm: Managerial Behavior, Agency Costs and Ownership Structure, Journal of Financial Economics No. 3

Jensen, C M dan R S Ruback, (1983), The Market for Corporate Control: The Scientific Evidence, Journal of Political Economy, 98, pp. 225264

Kaen, R. Fred, (2003), A Blueprint for Corporate Governance, American Management Association

Mace, M. L., (1986), dalam Morck (1992), The New Palgrave Dictionary of Money and Finance, Vol. 1 pp 475-477

Majalah SWA Sembada, No. 19/XVII/20 September - 3 Oktober 2001 
Manne, H. G, (1965), Mergers and the Market for Corporate Control, dalam Morck, K. Randall, (1992), Corporate Ownership and Management, dalam The New Palgrave Dictionary of Money and Finance, Vol. 1 pp 475-477

McConnell, J. J., dan H. Sevaes, (1990), dalam Morck, (1992), The Morck, K. Randall, (1992), Corporate Ownership and Management, dalam The New Palgrave Dictionary of Money and Finance, Vol. 1 pp 475-477

Morck, R., K., Andrei Shleifer, dan R. W. Vishny, (1989), Alternative Mechanisms for Corporate Control, American Economics Review 79 , pp $842-852$

Palepu, Krishna G., (1986), Predicting Takeover Targets; A Methodological and Empirical Analysis, Journal of Accounting and Economics, 8, pp. 3-35

Rozeff, Michael S., (1982), dalam Kim et al (1988), Investment Performance of Common Stocks in relation to Insider Ownership, The Financial Review, Vol. 23, No. 1, February pp 53- 63

Shleifer, Andrei dan R. W. Vishny (1986), Large Shareholders and Corporate Control, Journal of Political Economy, Vol. 94 No. 3 pp 461488

,(1997), A Survey of Corporate Governance, the Journal of Finance Vol. LIL. No. 2, June

Stulz, R (1988), dalam Morck, K. Randall, (1992), The New Palgrave Dictionary of Money and Finance, Vol. 1 pp 475-477

Weisbach, M., (1988) dalam Morck, (1992), The New Palgrave Dictionary of Money and Finance, Vol. 1 pp 475-477

Zingales, Luigi, (1994), The value of the Voting Right: A Study of the Milan Stock Exchage Experience, Review of Financial Studies, 7, pp.125-148 